\title{
KUALITAS UBI KENTANG PADA DOSIS PUPUK NPK DAN UMUR PANEN YANG BERBEDA
}

\section{QUALITY OF POTATO TUBER ON DIFFERENT NPK FERTILIZER DOSAGE AND HARVESTING TIME}

\author{
Kusumiyati* ${ }^{1}$, Diky Indrawibawa ${ }^{2}$, Syariful Mubarok $^{1}$, Gustiono Tegar Prasetyo $^{1}$ \\ ${ }^{1}$ Program Studi Agroteknologi, Fakultas Pertanian, Universitas Padjadjaran, Jalan Raya \\ Bandung-Sumedang Km.21, Jatinangor, Kab. Sumedang 45363 \\ ${ }^{2}$ CV. Bumi Agro Technology, Jalan Mekartani Kampung Kebon Cau, Cisarua \\ Bandung Barat 40551
}

*Korespondensi : kusumiyati@unpad.ac.id

Diterima : 11 April 2021 / Disetujui : 06 Juli 2021

\begin{abstract}
ABSTRAK
Semakin tingginya permintaan bahan baku kentang untuk french fries khususnya, perlu diimbangi oleh peningkatan suplai kentang dengan kualitas yang memenuhi persyaratan skala industri. Aplikasi dosis pupuk NPK yang tepat serta umur panen yang sesuai merupakan strategi dalam meningkatkan kualitas kentang. Penelitian bertujuan untuk menentukan dosis pupuk NPK dan umur panen yang dapat menghasilkan ubi kentang dengan kualitas olah terbaik. Percobaan dilakukan dengan menggunakan Rancangan Acak Kelompok pola faktorial dengan dua faktor dan tiga ulangan. Faktor pertama, yaitu dosis pupuk NPK $(50,100,150 \%$ dosis rekomendasi) dan umur panen $(90,105,120 \mathrm{HST})$. Hasil penelitian memperlihatkan bahwa perlakuan dosis pupuk NPK dan umur panen tidak memperlihatkan interaksi. Kadar air dan gula reduksi tidak dipengaruhi oleh perlakuan dosis pupuk dan umur panen. Perlakuan dosis pupuk $150 \mathrm{~kg} \mathrm{~N} \mathrm{ha}^{-1}, 225 \mathrm{~kg} \mathrm{P}^{-1}$, dan $225 \mathrm{~kg} \mathrm{~K}$ ha $^{-1}$ menunjukkan kadar pati ubi tertinggi dengan tingkat kerenyahan french fries paling disukai. Perlakuan umur panen 120 hari setelah tanam (HST) memberikan kadar pati dan tingkat kesukaan warna dan kerenyahan french fries paling tinggi.
\end{abstract}

Kata kunci: dosis pupuk, french fries, kualitas, Solanum tuberosum, umur panen

\section{ABSTRACT}

The potato demand is increasing, as a raw material for french fries in particular, yet followed by potato improvement to fulfil the industry requirement. The application of NPK fertilizer in appropriate dosage and harvesting time is the essential strategy to increase potato quality. This study aimed to determine the proper dosage of NPK and harvesting time to obtain the best characteristics of potato tuber for processing. The experimental design used a factorial randomized block design consisting of two factors; NPK fertilizer dosages $(50,100$, $150 \%$ recommended dosage) and harvesting time (90, 105, 120 DAP). NPK fertilizer dosage had no interaction with harvesting time. Tuber water content and reducing sugars were not affected by NPK fertilizer dosage and harvesting time. The treatment of $150 \mathrm{~kg} \mathrm{~N} \mathrm{ha}{ }^{-1}$,

ISSN : 2407-7933

Cite this as: Kusumiyati., Indrawibawa D., Mubarok S. \& Prasetyo G T. (2021). Kualitas ubi kentang pada dosis pupuk NPK dan umur panen yang berbeda. Jurnal Agro, 8(1), 14-24. https://doi.org/10.15575/12292 
$225 \mathrm{~kg} \mathrm{P}$ ha-1 and $225 \mathrm{~kg} \mathrm{~K}$ ha-1 had the best tuber starch content, and after processing to be french fries, it showed the most favored crispness. Meanwhile, harvesting time at 120 DAP resulted in the highest tuber starch content, french fries colour and crispness score. Giving a certain dose of NPK fertilizer will affect the quality of potato tubers. The right harvesting time affects on the potato tuber quality.

Key words : fertilizer dosage, french fries, harvesting time, quality, Solanum tuberosum

\section{PENDAHULUAN}

French fries merupakan salah satu olahan kentang yang cukup digemari masyarakat. Kentang kultivar Atlantik dikenal sangat cocok digunakan sebagai bahan baku french fries, namun ketersediaannya terbatas karena bibit kultivar ini masih diimpor dari luar. Pemanfaatan tanaman kentang kultivar Jala Ipam sebagai bahan baku french fries dapat dilakukan sebagai upaya dalam memenuhi permintaan di tingkat industri. Ubi kentang kultivar Jala Ipam cocok dikonsumsi dalam bentuk french fries karena memiliki daging ubi yang berwarna putih, kandungan pati tinggi, dan kandungan gula rendah (Munggarani et al., 2018).

Permintaan bahan baku ubi kentang pada skala industri memperlihatkan tren peningkatan, termasuk pada french fries. Untuk menembus pasar modern dibutuhkan ubi kentang berkualitas tinggi (Sutrisna \& Surdianto, 2014). Komposisi nutrisi dan komponen kualitas pada ubi dipengaruhi oleh suplai dan ketersediaan unsur hara di dalam tanah, terutama unsur nitrogen $(\mathrm{N})$, fosfor $(\mathrm{P})$, dan kalium $(\mathrm{K})$ (Naumann et al., 2020).

Tanaman kentang yang cukup unsur $\mathrm{N}$ akan lebih tahan terhadap penyakit dan menghasilkan ubi dengan gula reduksi rendah serta bahan kering tinggi (Muleta \& Aga, 2019). Unsur $P$ dapat meningkatkan kandungan pati di dalam ubi serta meningkatkan persentase ubi layak pasar (Fernandes et al., 2015). Aplikasi pupuk kalium memacu akumulasi bahan kering, sintesis pati, vitamin C, serta protein di dalam ubi (Xing et al., 2020).

Selama siklus hidupnya, tanaman kentang memerlukan unsur $\mathrm{N}$ sebesar $100-$ $150 \mathrm{~kg} \mathrm{ha}^{-1}$, unsur P 100-150 kg ha-1, dan unsur K $150 \mathrm{~kg} \mathrm{ha}^{-1}$ (Hilman \& Suwandi, 1987). Sandhu et al. (2014) juga memaparkan bahwa dosis pupuk NPK rekomendasi untuk kentang yaitu masingmasing 150, 50, dan $100 \mathrm{~kg} \mathrm{ha}^{-1}$. Namun demikian, kebutuhan pupuk untuk tanaman kentang bergantung pada jenis tanah, ketersediaan nutrisi, dan varietas yang digunakan (Misgina, 2016). Pemupukan NPK perlu dilakukan dengan dosis yang sesuai dengan kebutuhan hara tanaman, atau dengan kata lain besaran pupuk yang diberikan harus sama dengan hara yang diserap tanaman (Ginting et al., 2017).

Umur panen kentang kultivar Jala Ipam berkisar 90-105 hari setelah tanam (HST). Umur panen juga mempengaruhi kualitas olahannya, karena terdapat titik optimal pada umur tertentu dimana ubi kentang memiliki kandungan nutrisi, terutama kadar pati yang tinggi dan tidak akan mengalami penambahan kembali (Kusdibyo \& Asandhi, 2004).

Hasil penelitian Söğüt \& Öztürk (2011) menunjukan bahwa penundaan panen hingga 120 HST memperlihatkan kadar pati, berat jenis, dan bahan kering yang lebih 
tinggi daripada 90 HST pada beberapa kultivar kentang. Umur panen yang lebih tua meningkatkan bahan kering dan akumulasi pati di dalam ubi kentang (Rymuza et al., 2015). Oleh karena itu, ubi kentang perlu dipanen pada waktu yang tepat agar memiliki karakter fisik dan komposisi kimia yang memenuhi standar industri.

Penelitian mengenai dosis pupuk NPK dan umur panen yang sesuai pada tanaman kentang masih sangat terbatas, terutama pada pemanfaatan kultivar Jala Ipam sebagai bahan baku french fries. Berdasarkan hal tersebut, maka tujuan dari penelitian ini adalah untuk menentukan dosis pupuk NPK dan umur panen yang dapat menghasilkan ubi kentang kultivar Jala Ipam dengan kualitas olah terbaik.

\section{BAHAN DAN METODE}

Penelitian dilaksanakan pada Desember 2017 - April 2018 di CV. Bumi Agro Technology, Cisarua, Jawa Barat (1250 m dpl). Jenis tanah yang digunakan adalah tanah ordo Andisol. Bahan yang digunakan meliputi benih kentang kultivar Jala Ipam $\mathrm{G}_{0}$, pupuk urea $(46 \% \mathrm{~N}), \mathrm{SP}-36\left(36 \% \mathrm{P}_{2} \mathrm{O}_{5}\right)$, $\mathrm{KCl}\left(60 \% \mathrm{~K}_{2} \mathrm{O}\right)$; pupuk kompos sapi (20 tha${ }^{1}$ ), insektisida Demolish 18 EC (bahan aktif Abamektin $18 \mathrm{~g} \mathrm{~L} \mathrm{~L}^{-1}$ ), dan fungisida Raincozeb 80 WP (bahan aktif mancozeb $80 \%$ ). Alat-alat yang digunakan adalah mulsa plastik hitam perak, meteran, timbangan analitik, oven, dan desikator.

Penelitian menggunakan metode eksperimen di lapangan menggunakan Rancangan Acak Kelompok faktorial dengan dua faktor. Faktor ke-1 yaitu dosis pupuk NPK dengan taraf $50 \%$ dosis rekomendasi (50 kg N ha ${ }^{-1}, 75 \mathrm{~kg} \mathrm{P} \mathrm{ha}^{-1}, 75 \mathrm{~kg} \mathrm{~K} \mathrm{ha}^{-1}$ ), $100 \%$ dosis rekomendasi (100 kg N ha ${ }^{-1}, 150$ kg $\mathrm{P} \mathrm{ha}{ }^{-1}, 150 \mathrm{~kg} \mathrm{~K} \mathrm{ha}{ }^{-1}$ ), dan $150 \%$ dosis rekomendasi (150 kg N ha ${ }^{-1}, 225 \mathrm{~kg} \mathrm{P} \mathrm{ha}^{-1}$, $\left.225 \mathrm{~kg} \mathrm{~K} \mathrm{ha}^{-1}\right)$. Faktor kedua yaitu umur panen dengan taraf 90 HST, 105 HST, dan 120 HST. Setiap perlakuan diulang sebanyak tiga kali. Tanaman kentang ditanam pada bedengan yang dilapisi mulsa plastik hitam perak. Pupuk kompos sapi, SP-36 dan KCl diaplikasikan saat tanam. Sementara setengah dosis pupuk urea diaplikasikan pada saat tanam, kemudian setengah dosis berikutnya diberikan kembali saat 30 HST.

Parameter yang diamati meliputi hasil analisis tanah awal, komponen kualitas ubi kentang yaitu kadar air dengan metode Gravimetri (Sudarmadji, 1984), kadar pati dan gula reduksi dengan metode Luff Schoorl (AOAC, 1995), kemudian dilanjutkan uji organoleptik. Tahapan untuk uji organoleptik dimulai dengan mengupas ubi kentang, kemudian hasil kupasan direndam di dalam air. Ubi kentang diiris dengan perajang khusus dengan ketebalan irisan $\pm 0,64 \mathrm{~cm}$, kemudian digoreng dalam minyak pada suhu $177^{\circ} \mathrm{C}$ selama \pm 3 menit (Gould \& Plimpton, 1985). Sampel french fries dimasukan ke dalam plastik yang telah diberi label untuk diuji berdasarkan tingkat kesukaan pada warna, rasa, dan kerenyahan oleh 15 panelis yang merupakan konsumen french fries. Tingkat kesukaan diimplementasikan dalam bentuk skor (1: sangat tidak suka, 2: tidak suka, 3: biasa, 4 : suka, 5 : sangat suka).

Data dianalisis berdasarkan Analisis Sidik Ragam (ANOVA) menggunakan software SPSS 21 dan dilanjutkan dengan Uji Tukey pada taraf $5 \%$ untuk mengetahui signifikansi antar perlakuan. Sementara data uji organoleptik dianalisis secara deskriptif. 


\section{HASIL DAN PEMBAHASAN}

\section{Hasil Analisis Tanah Awal}

Hasil analisis tanah awal menunjukkan bahwa tanah Andisol pada percobaan ini memiliki pH 6 (agak masam). Kemudahan penyerapan unsur hara oleh tanah ditentukan oleh $\mathrm{pH}$ tanah. Tanah yang memiliki pH 7, unsur hara di dalamnya akan mudah larut sehingga akan lebih mudah diserap oleh tanah (Yuniarti et al., 2017). Selain itu, kandungan C-organik 6,55\% (sangat tinggi), $\mathrm{N}$-total 0,75\% (tinggi), $\mathrm{C} / \mathrm{N} 9$ (rendah), total $\mathrm{P}_{2} \mathrm{O}_{5} 167,94 \mathrm{mg} 100 \mathrm{~g}^{-1}$ (sangat tinggi), dan $\mathrm{K}_{2} \mathrm{O} 81,97 \mathrm{mg} 100 \mathrm{~g}^{-1}$ (sangat tinggi). Berdasarkan hasil tersebut maka tanah Andisol tergolong tanah yang cukup subur.

Walaupun demikian, kentang merupakan tanaman yang mengambil hara dalam jumlah yang besar di dalam tanah setiap waktunya, sehingga tanah harus mampu memenuhi kebutuhan hara dari tanaman (Nityamanjari, 2018). Hasil analisis tanah dapat dijadikan sebagi tolak ukur dalam memprediksi dosis pupuk yang diperlukan

\section{Kadar Air Ubi}

Dosis pupuk NPK dan umur panen tidak menunjukan interaksi terhadap kadar air ubi (Tabel 1). Perlakuan dosis pupuk NPK tidak berpengaruh nyata terhadap kadar air ubi (Tabel 2). Semakin meningkat dosis pupuk cenderung semakin menurunkan kadar air. Ubi kentang mengandung sekitar $80 \%$ air dan $20 \%$ bahan kering yang keduanya berkorelasi negatif. Sebesar $60-$ 80\% dari bahan kering tersebut merupakan pati (Ekin, 2011). Berdasarkan pengamatan kadar pati pada Tabel 2, dosis pupuk $150 \mathrm{~kg}$ $\mathrm{N}$ ha ${ }^{-1}, 225 \mathrm{~kg} \mathrm{P} \mathrm{ha}{ }^{-1}$, dan $225 \mathrm{~kg} \mathrm{~K} \mathrm{ha}^{-1}$ menunjukan kadar pati paling tinggi daripada dosis pupuk lainnya, sehingga diduga menurunkan kadar air ubi.

Perlakuan umur panen tidak berpengaruh nyata pada kadar air ubi (Tabel 2). Saleh (2018) menyatakan bahwa perbedaan umur panen pada bawang merah tidak mempengaruhi kadar air umbi. Kadar air ubi yang tinggi menyebabkan olahan kentang menjadi lembek, sedangkan kadar air yang rendah dapat mencegah hancurnya kentang ketika digoreng (Haryanti et al., 2013). Kadar air yang dikehendaki sebagai syarat kentang olahan adalah hingga 83,3\% (Asgar et al., 2011), sehingga kadar air kentang dalam percobaan ini telah memenuhi standar tersebut, baik pada perlakuan dosis pupuk NPK maupun umur panen.

Tabel 1. Nilai probabilitas kadar air, kadar pati, dan gula reduksi pada perlakuan dosis pupuk NPK dan umur panen.

\begin{tabular}{cccc}
\hline $\begin{array}{c}\text { Penga- } \\
\text { matan }\end{array}$ & $\begin{array}{c}\text { Dosis } \\
\text { Pupuk }\end{array}$ & $\begin{array}{c}\text { Umur } \\
\text { Panen }\end{array}$ & Interaksi \\
\hline $\begin{array}{c}\text { Kadar } \\
\text { Air }\end{array}$ & $0,2516^{\text {ns }}$ & $0,4428^{\text {ns }}$ & $0,061^{\text {ns }}$ \\
$\begin{array}{c}\text { Kadar } \\
\text { Pati }\end{array}$ & $0,0006^{*}$ & $0,0112^{*}$ & $0,908^{\text {ns }}$ \\
$\begin{array}{c}\text { Gula } \\
\text { Reduksi }\end{array}$ & $0,2318^{\text {ns }}$ & $0,6208^{\text {ns }}$ & $0,090^{\text {ns }}$ \\
\hline
\end{tabular}

Ket: *berbeda nyata $(p<0,05) ;{ }^{\text {ns }}$ tidak berbeda nyata $(p>0,05)$

\section{Kadar Pati Ubi}

Dosis pupuk NPK dan umur panen tidak menunjukan interaksi terhadap kadar pati ubi (Tabel 1). Perlakuan dosis pupuk $150 \mathrm{~kg}$ $\mathrm{N} \mathrm{ha}{ }^{-1}, 225 \mathrm{~kg} \mathrm{P} \mathrm{ha}^{-1}$, dan $225 \mathrm{~kg} \mathrm{~K} \mathrm{ha}^{-1}$ memperlihatkan kadar pati ubi paling tinggi dan berbeda nyata dengan perlakuan lainnya (Tabel 2). El-Hadidi et al., (2017) melaporkan bahwa aplikasi $150 \mathrm{~kg} \mathrm{~N} \mathrm{ha}^{-1}$ menghasilkan kadar pati ubi kentang paling baik (15,73\%). Peningkatan dosis pupuk $\mathrm{K}$ hingga $270 \mathrm{~kg} \mathrm{ha}^{-1}$ memperoleh kadar pati 
ubi kentang kultivar Atlantik yang lebih tinggi daripada dosis $135 \mathrm{~kg} \mathrm{~K} \mathrm{ha}^{-1}$ (Zhang et al., 2018). Kalium berfungsi menstimulasi aktivitas enzim pati sintase yang berperan mengkatalis molekul glukosa sederhana menjadi molekul pati yang kompleks di dalam ubi kentang (Mokrani et al., 2018).

Tabel 2. Kadar air, kadar pati, dan gula reduksi ubi kentang pada dosis pupuk NPK dan umur panen yang berbeda.

\begin{tabular}{lccc}
\hline \multicolumn{1}{c}{ Perlakuan } & $\begin{array}{c}\text { Kadar Air } \\
\text { (\%) }\end{array}$ & $\begin{array}{c}\text { Kadar Pati } \\
\text { (\%) }\end{array}$ & $\begin{array}{c}\text { Gula Reduksi } \\
\text { (\%) }\end{array}$ \\
\hline Dosis Pupuk NPK (kg ha ${ }^{-1}$ ) & & & \\
50 kg N, 75 kg P, dan 75 kg K & $82,75 \mathrm{a}$ & $14,02 \mathrm{a}$ & $0,12 \mathrm{a}$ \\
$100 \mathrm{~kg} \mathrm{~N}, 150 \mathrm{~kg} \mathrm{P,} \mathrm{dan} \mathrm{150} \mathrm{kg} \mathrm{K}$ & $81,69 \mathrm{a}$ & $13,99 \mathrm{a}$ & $0,13 \mathrm{a}$ \\
$150 \mathrm{~kg} \mathrm{~N}, 225 \mathrm{~kg} \mathrm{P}$, dan 225 kg K & $81,67 \mathrm{a}$ & $15,44 \mathrm{~b}$ & $0,11 \mathrm{a}$ \\
Umur Panen (HST) & & & \\
90 & $81,77 \mathrm{a}$ & $14,14 \mathrm{a}$ & $0,12 \mathrm{a}$ \\
105 & $81,80 \mathrm{a}$ & $14,43 \mathrm{ab}$ & $0,13 \mathrm{a}$ \\
120 & $82,55 \mathrm{a}$ & $14,88 \mathrm{~b}$ & $0,12 \mathrm{a}$ \\
\hline
\end{tabular}

Ket: Nilai yang diikuti huruf yang berbeda pada kolom yang sama menyatakan berbeda signifikan menurut Uji Tukey $(p<0,05)$.

Perlakuan umur panen berpengaruh nyata terhadap kadar pati ubi kentang (Tabel 2). Perlakuan umur panen 120 HST menunjukan kadar pati lebih tinggi dibandingkan dengan panen umur 90 HST, namun tidak berbeda nyata dengan panen pada umur 105 HST. Penundaan panen pada kentang dapat meningkatkan kadar pati di dalam ubi karena masih terjadi proses fotosintesis yang menyebabkan akumulasi pati pada ubi akan meningkat (Sharkar et al., 2019). Ubi yang umur panennya lebih lama memiliki bahan kering yang tinggi dan selanjutnya tidak akan mengalami peningkatan yang berarti lagi (Solaiman et al., 2015).

Kadar pati dalam penelitian ini yaitu berkisar 13,99-15,44\%, pada perlakuan dosis pupuk NPK dan umur panen. Sebagai pembanding, Kusandriani (2014) melaporkan bahwa kadar pati ubi kentang kultivar Atlantik yaitu 8,464\%. Dengan demikian, tampaknya ubi kentang kultivar Jala Ipam berpotensi menghasilkan kualitas kadar pati yang lebih baik. Kadar pati ubi yang tinggi sangat diperlukan untuk olahan kentang, karena akan meningkatkan kerenyahan.

\section{Gula Reduksi Ubi}

Gula reduksi merupakan gula yang mampu untuk mereduksi. Hal tersebut dikarenakan gula reduksi memiliki keton bebas atau gugus aldehid. Beberapa faktor yang mempengaruhi jumlah gula reduksi adalah genotip, lingkungan, kultur teknis, penanganan pascapanen, dan kondisi penyimpanan (Asgar et al., 2011; Ndungutse et al., 2019).

Dosis pupuk NPK dan umur panen tidak menunjukan interaksi terhadap gula reduksi ubi (Tabel 1). Perlakuan dosis pupuk NPK tidak memberikan pengaruh nyata terhadap gula reduksi ubi (Tabel 2). Menurut Bărăscu et al. (2016), aplikasi dosis pupuk $\mathrm{N}$ sebesar 100 dan $200 \mathrm{~kg} \mathrm{ha}^{-1}$ tidak mempengaruhi gula reduksi ubi kentang kultivar Roclas. Rosen et al. (2014) menyatakan bahwa aplikasi pupuk $\mathrm{P}$ juga tidak mempengaruhi gula reduksi ubi kentang, karena unsur $P$ 
berperan lebih penting dalam menghadapi faktor iklim dan edafik dibandingkan kualitas ubi kentang.

Perlakuan umur panen juga tidak berpengaruh nyata terhadap gula reduksi ubi (Tabel 2). Kusdibyo \& Asandhi (2004) melaporkan bahwa kentang yang dipanen saat umur 70, 80, 90, 100 dan 110 HST tidak berpengaruh nyata terhadap gula reduksi ubi. Komposisi gula di dalam ubi berfluktuasi selama tahap perkembangan ubi. Ubi yang belum matang memiliki kadar fruktosa yang tinggi, kemudian gula reduksi menurun selama tahap pembesaran ubi, dan naik kembali ke level moderat sebelum tahap pematangan ubi (Petropoulos et al., 2020).

Menurut Brar et al. (2017), syarat kadar gula reduksi ubi kentang agar dapat diolah menjadi french fries adalah lebih kecil dari $0,5 \%$. Pada penelitian ini, kadar gula reduksi berkisar $0,11-0,13 \%$ pada perlakuan dosis pupuk NPK dan umur panen, sehingga telah memenuhi standar bahan baku kentang untuk french fries. Rendahnya kadar gula reduksi diperlukan untuk menghindari warna gelap dan rasa pahit pada french fries.

\section{Uji Organoleptik \\ Warna}

Skor tertinggi tingkat kesukaan pada warna diperoleh pada perlakuan $100 \mathrm{~kg} \mathrm{~N}$ $\mathrm{ha}^{-1}, 150 \mathrm{~kg} \mathrm{P} \mathrm{ha}^{-1}$, dan $150 \mathrm{~K} \mathrm{~kg} \mathrm{ha}^{-1}$ dengan skor 3,53 atau pada tingkat kesukaan biasa (Tabel 3). Walaupun demikian, rentang skor warna pada perlakuan dosis pupuk NPK lainnya adalah 3,33-3,47, sehingga termasuk dalam kategori yang sama. Kumar et al. (2015) mengungkapkan bahwa penambahan dosis pupuk pada kentang dari dosis rekomendasi $\left(270 \mathrm{~kg} \mathrm{~N}^{-1}, 80 \mathrm{~kg} \mathrm{P}\right.$ $\mathrm{ha}^{-1}, 150 \mathrm{~kg} \mathrm{~K} \mathrm{ha}^{-1}$ ) menunjukan skor warna french fries dengan kategori yang sama antar perlakuan. Warna olahan kentang dipengaruhi oleh kadar gula reduksi (Gunarto, 2012). Berdasarkan Tabel 2, seluruh perlakuan dosis NPK menghasilkan kadar gula reduksi yang tidak berpengaruh nyata, sehingga diduga tingkat kesukaan terhadap warna juga tidak berbeda jauh antar perlakuan.

Tabel 3. Skor tingkat kesukaan warna, rasa, dan kerenyahan french fries hasil pengolahan ubi kentang pada dosis pupuk NPK dan umur panen yang berbeda.

\begin{tabular}{lccc}
\hline \multicolumn{1}{c}{ Perlakuan } & Warna & Rasa & Kerenyahan \\
\hline Dosis Pupuk NPK (kg ha-1) & & & \\
$50 \mathrm{~kg} \mathrm{~N}, 75 \mathrm{~kg} \mathrm{P}$, dan 75 kg K & 3,33 & 3,27 & 3,40 \\
$100 \mathrm{~kg} \mathrm{~N}, 150 \mathrm{~kg} \mathrm{P}$, dan 150 kg K & 3,53 & 3,60 & 3,47 \\
$150 \mathrm{~kg} \mathrm{~N}, 225 \mathrm{~kg} \mathrm{P}$, dan 225 kg K & 3,47 & 3,47 & 3,67 \\
Umur Panen (HST) & & & \\
90 & 3,20 & 3,40 & 3,40 \\
105 & 3,53 & 3,53 & 3,53 \\
120 & 3,60 & 3,40 & 3,60 \\
\hline
\end{tabular}

Berdasarkan Tabel 3, penundaan panen kentang hingga 120 HST memberikan skor tingkat kesukaan warna paling tinggi yaitu 3,60 (biasa). Skor yang dihasilkan pada perlakuan umur panen yaitu $3,20-3,60$ atau pada kategori biasa. Asgar (2013) mengungkapkan bahwa waktu panen kentang yang sesuai untuk bahan baku keripik yaitu ketika tanaman berumur 100 hari. 
Umumnya french fries yang berwarna kuning lebih disukai daripada cokelat. Saat kentang digoreng pada suhu tinggi, terjadi pembentukan akrilamida melalui reaksi Maillard (browning) pada asparagin dan gula reduksi (fruktosa dan glukosa). Reaksi Maillard menyebabkan warna cokelat pada french fries dan jika berwarna terlalu gelap maka rasanya akan pahit (McCombie et al., 2016)

\section{Rasa}

Berdasarkan Tabel 3, dosis pupuk $100 \%$ rekomendasi (100 kg N ha ${ }^{-1}, 150 \mathrm{~kg} \mathrm{P} \mathrm{ha}^{-1}$, dan $150 \mathrm{~K} \mathrm{~kg} \mathrm{ha}{ }^{-1}$ ) menghasilkan skor tingkat kesukaan rasa paling tinggi yaitu 3,60 (biasa). Sementara skor dosis pupuk 50 dan $150 \%$ dosis rekomendasi yaitu masingmasing 3,27 dan 3,47 atau masih dalam kategori biasa. Hasil penelitian Khan et al. (2012) menunjukan bahwa aplikasi 150 dan $225 \mathrm{~kg} \mathrm{~K} \mathrm{ha}^{-1}$ memiliki skor warna yang lebih baik daripada tanpa pemupukan $\mathrm{K}$. Kurangnya unsur $\mathrm{K}$ dalam tanaman akan memicu konversi pati menjadi gula di dalam ubi (Bhattarai \& Swarnima, 2016).

Skor tingkat kesukaan rasa tertinggi diperoleh pada perlakuan umur panen 105 HST yaitu 3,53 (biasa) (Tabel 3). Rentang skor yang dihasilkan dari perlakuan umur panen adalah 3,40-3,53 yang juga masuk dalam kategori tingkat kesukaan biasa. Rasa pahit pada kentang akan timbul ketika gula reduksi tinggi. Tidak berpengaruh nyatanya gula reduksi pada percobaan ini diduga menyebabkan tingkat kesukaan rasa french fries hampir sama antar perlakuan. Sato et al. (2019) menambahkan bahwa rasa agak pahit pada olahan kentang juga dapat disebabkan oleh tingginya kadar tirosin yang dapat menurunkan kualitas kentang.

\section{Kerenyahan}

Perlakuan dosis pupuk $150 \%$ rekomendasi (150 kg N ha- ${ }^{-1}, 225 \mathrm{~kg} \mathrm{P} \mathrm{ha}^{-1}$, dan $225 \mathrm{~K} \mathrm{~kg} \mathrm{ha}^{-1}$ ) memberikan skor tingkat kesukaan kerenyahan paling tinggi, yaitu 3,67 atau kategori biasa (Tabel 3). Rentang skor kerenyahan pada perlakuan dosis pupuk NPK yaitu 3,40-3,67 (biasa). Walaupun demikian, semakin tinggi dosis pupuk NPK tampak semakin meningkatkan skor kerenyahan. Flis et al. (2017) mengungkapkan bahwa kadar pati berperan penting dalam menentukan kerenyahan, walaupun bukan satu-satunya faktor yang mempengaruhi. Berdasarkan Tabel 1, perlakuan $150 \%$ dosis rekomendasi $(150 \mathrm{~kg}$ $\mathrm{N} \mathrm{ha}^{-1}, 225 \mathrm{~kg} \mathrm{P} \mathrm{ha}^{-1}, 225 \mathrm{~kg} \mathrm{~K} \mathrm{ha}{ }^{-1}$ ) memperoleh kadar pati paling tinggi, sehingga diduga meningkatkan kerenyahan french fries.

Penundaan panen hingga umur 120 HST memperoleh skor tingkat kesukaan kerenyahan paling tinggi yaitu 3,60 atau biasa (Tabel 3). Rentang skor kerenyahan pada perlakuan umur panen yaitu 3,40 3,60 (biasa). Semakin lama umur panen menampilkan skor kerenyahan yang lebih tinggi. Hasil penelitian Abong et al. (2009) menunjukan peningkatan skor kerenyahan french fries pada kentang varietas Tigoni yang dipanen hingga 120 HST, walaupun masih dalam kategori kesukaan yang sama. Amilopektin di dalam pati merupakan senyawa yang dapat memberikan kerenyahan pada bahan. Kerenyahan akan diperoleh ketika bahan bersifat padat dan lebih mudah patah (Perdani et al., 2019).

\section{SIMPULAN}

1. Tidak terdapat interaksi pada perlakuan dosis pupuk NPK dan umur 
panen terhadap komponen kualitas kentang kultivar Jala Ipam.

2. Kadar air dan gula reduksi tidak dipengaruhi oleh perlakuan dosis pupuk dan umur panen.

3. Perlakuan $150 \%$ dosis pupuk rekomendasi (150 kg N ha ${ }^{-1}, 225 \mathrm{~kg} \mathrm{P}$ $\mathrm{ha}^{-1}$, dan $225 \mathrm{~kg} \mathrm{~K} \mathrm{ha}^{-1}$ ) menunjukkan kadar pati ubi paling tinggi dengan tingkat kerenyahan french fries yang paling disukai panelis.

4. Perlakuan umur panen 120 HST memberikan kadar pati dan tingkat kesukaan warna dan kerenyahan french fries paling tinggi.

\section{DAFTAR PUSTAKA}

AOAC. (1995). Official methods of analysis. Washington: Association of Official Analytical Chemists International.

Abong, G., Okoth, M., Karuri, E., Kabira, J., \& Mathooko, F. (2009). Influence of potato cultivar and stage of maturity on oil content of french fries (chips) made from eight Kenyan potato cultivars. African Journal of Food, Agriculture, Nutrition and Development, 9(8), 1667-1682. https://doi.org/10.4314/ajfand.v9i8.4 8405

Asgar, A. (2013). Kualitas umbi beberapa klon kentang (Solanum tuberosum L.) dataran medium untuk keripik. Berita Biologi, 12(1), 29-37.

Asgar, A., Kusmana, Rahayu, S. T., \& Sofiari, E. (2011). Uji kualitas umbi beberapa klon kentang untuk keripik. Jurnal Hortikultura, 21(1), 51-59. https://doi.org/10.21082/jhort.v21n1. 2011.p51-59

Barascu, N., lanosi, M., Duda, M., \& Muntean, E. (2016). The NPK fertilization effects of tubers starch, dry matter and reducing sugar content. Scientific Papers-Series A, Agronomy, 59, 194-199.

Bhattarai, B., \& Swarnima, K. C. (2016). Effect of potassium on quality and yield of potato tubers - a review. International Journal of Agriculture \& Environmental Science, 3(6), 7-12. https://doi.org/10.14445/23942568/ij aes-v3i6p103

Brar, A., Bhatia, A. K., Pandey, V., \& Kumari, P. (2017). Biochemical and phytochemical properties of potato: a review. Chemical Science Review and Letters, 6(21), 117-129.

Ekin, Z. (2011). Some analytical quality characteristics for evaluating the utilization and consumption of potato (Solanum tuberosum L.) tubers. African Journal of Biotechnology, 10(32), 6001-6010. https://doi.org/10.5897/AJB11.042

El-Hadidi, E., Ewais, M., \& Shehata, A. (2017). Fertilization effects on potato yield and quality. Journal of Soil Sciences and Agricultural Engineering, 8(12), 769-778. https://doi.org/10.21608/jssae.2017.3 8254

Fernandes, A. M., Soratto, R. P., Moreno, L. de A., \& Evangelista, R. M. (2015). Effect of phosphorus nutrition on quality of fresh tuber of potato cultivars. Bragantia, 74(1), 102-109. https://doi.org/10.1590/16784499.0330

Flis, B., Tatarowska, B., Milczarek, D., \& Plich, J. (2017). Effect of location on starch content and tuber texture characteristics in potato breeding lines and cultivars. Acta Agriculturae Scandinavica Section B: Soil and Plant Science, 67(5), 453-461. https://doi.org/10.1080/09064710.20 17.1299792

Ginting, S. L. B., Sunaryo, Y., \& Prasetyowati, 
S. E. (2017). Pengaruh dosis pupuk NPK dan konsentrasi pupuk organik cair terhadap pertumbuhan dan hasil tanaman tomat (Lycopersicum esculentum Mill) dalam polibag. Jurnal IImiah Agroust, 1(1), 24-33.

Gould, W. A. \& Plimpton, S. (1985). Quality evaluation of potato cultivars for processing. Ohio: North Central Regional Research Publication 305

Gunarto, A. (2012). Preferensi panelis pada tiga klon kentang terhadap kultivar Granola dan Atlantik. Jurnal Sains Dan Teknologi Indonesia, 14(1), 6-11. https://doi.org/10.29122/jsti.v14i1.89 8

Haryanti, P., Sustriawan, B., \& Sujiman. (2013). Perendaman dalam kalsium klorida dan penggunaan edible coating untuk meningkatkan kualitas french fries dari kentang varietas Tenggo dan Krespo. Agritech, 33(1), 38-45.

Hilman, Y., \& Suwandi. (1987). Pengaruh penggunaan pupuk nitrogen dan fosfat terhadap mutu umbi kentang. Buletin Penelitian Hortikultura, 15(1), 72-78.

Khan, M. Z., Akhtar, M. E., Mahmood-ulHassan, M., Mahmood, M. M., \& Safdar, M. N. (2012). Potato tuber yield and quality as affected by rates and sources of potassium fertilizer. Journal of Plant Nutrition, 35(5), 664677.

https://doi.org/10.1080/01904167.20 12.653072

Kumar, P., Kumar, R. K., Sciences, J. L., Kumar, D., \& Singh, B. P. (2015). Fertilizer management of potato (Solanum tuberosum) variety Kufri Frysona for higher yield, good fry quality, profitability and storability. Ann. Agric. Res. New Series, 36(2), 191-199.

Kusandriani, Y. (2014). Uji daya hasil dan kualitas delapan genotip kentang untuk industri keripik kentang nasional berbahan baku lokal. Jurnal Hortikultura, 24(4), 283-288. https://doi.org/10.21082/jhort.v24n4. 2014.p283-288

Kusdibyo, \& Asandhi, A. A. (2004). Waktu panen dan penyimpanan pasca panen untuk mempertahankan mutu umbi kentang olahan. Ilmu Pertanian, 11(1), 51-62.

McCombie, G., Biedermann, M., Biedermann-Brem, S., Suter, G., Eicher, A., \& Pfefferle, A. (2016). Acrylamide in a fried potato dish (rösti) from restaurants in Zurich, Switzerland. Food Additives and Contaminants: Part B Surveillance, 9(1), 21-26. https://doi.org/10.1080/19393210.20 15.1102974

Misgina, N. A. (2016). Effect of phosphorus and potassium fertilizer rates on yield and yield component of potato (Solanum tubersum L) at K/Awlaelo, Tigray, Ethiopia. Food Science and Quality Management, 48, 60-69.

Mokrani, K., Hamdi, K., \& Tarchoun, N. (2018). Potato (Solanum tuberosum L.) response to nitrogen, phosphorus and potassium fertilization rates. Communications in Soil Science and Plant Analysis, 49(11), 1314-1330. https://doi.org/10.1080/00103624.20 18.1457159

Muleta, H. D., \& Aga, M. C. (2019). Role of nitrogen on potato production: a review. Journal of Pant Sciences, 7(2), 36-42.

https://doi.org/10.11648/j.jps.201907 02.11

Munggarani, M., Suminar, E., Nuraini, A., \& Mubarok, S. (2018). Multiplikasi tunas meriklon kentang pada berbagai jenis dan konsentrasi sitokinin. Agrologia, 7(2), 80-89. https://doi.org/10.30598/a.v7i2.766

Naumann, M., Koch, M., Thiel, H., Gransee, 
A., \& Pawelzik, E. (2020). The importance of nutrient management for potato production part II: plant nutrition and tuber quality. Potato Research, 63(1), 121-137. https://doi.org/10.1007/s11540-01909430-3

Ndungutse, V., Ngoda, P. M. N., Vasanthakaalam, H., Shakala, E. K., \& Faraj, A. K. (2019). Processing quality of selected potato (Solanum tuberosum L.) cultivars grown in Rwanda. Potato Journal, 46(1), 48-55.

Nityamanjari, M. (2018). Effect of fertilizers on growth and productivity of potatoa review. International Journal of Agriculture Sciences, 10(4), 51835186. https://doi.org/10.9735/09753710.10.4.5183-5186

Perdani, C. G., Amaludin, F. N., \& Wijana, S. (2019). Formulasi kerupuk kentang Granola (Solanum tuberosum L.) sebagai makanan kuliner khas Tengger Jawa Timur. Jurnal Pangan Dan Agroindustri, 7(3), 37-48. https://doi.org/10.21776/ub.jpa.2019. 007.03.5

Petropoulos, S. A., Fernandes, Â., Polyzos, N., Antoniadis, V., Barros, L., \& Ferreira, I. C. F. R. (2020). The impact of fertilization regime on the crop performance and chemical composition of potato (Solanum tuberosum L.) cultivated in central Greece. Agronomy, 10(4), 1-18. https://doi.org/10.3390/agronomy100 40474

Rosen, C. J., Kelling, K. A., Stark, J. C., \& Porter, G. A. (2014). Optimizing phosphorus fertilizer management in potato production. American Journal of Potato Research, 91(2), 145-160. https://doi.org/10.1007/s12230-0149371-2

Rymuza, K., Pawlonka, Z., Stopa, D., Starczewski, K., \& Bombik, A. (2015). The effect of ridge height and harvest date on edible potato tuber quality. Bulgarian Journal of Agricultural Science, 21(3), 611-617. https://doi.org/10.2478/jppr-20140034

Saleh, I. (2018). Karakteristik dan viabilitas bibit bawang merah pada waktu panen berbeda. Jurnal Hexagro, 2(1), 30-35.

Sandhu, A. S., Sharma, S. P., Bhutani, R. D., \& Khurana, S. C. (2014). Effects of planting date and fertilizer dose on plant growth attributes and nutrient uptake of potato (Solanum tuberosum L.). International Journal of Agricultural Sciences, 4(5), 196-202.

Sato, H., Koizumi, R., Itoyama, R., Ichisawa, M., Negishi, J., Sakuma, R., Furusho, T., Sagane, Y., \& Takano, K. (2019). Free amino acids in potato (Solanum tuberosum) may cause egumi-taste in food products. Potato Research, 62(3), 305-314. https://doi.org/10.1007/s11540-0199412-9

Sharkar, M., Ahmed, J., Ahmed, S., Meraj, S. Al, \& Din, M. M. U. (2019). Effect of harvesting dates on the yield and tuber quality of processing potatoes. Bangladesh Journal of Agricultural Research, 44(1), 179-193. https://doi.org/10.3329/bjar.v44i1.40 940

Söğüt, T., \& Öztürk, F. (2011). Effects of harvesting time on some yield and quality traits of different maturing potato cultivars. African Journal of Biotechnology, 10(38), 7349-7355. https://doi.org/10.5897/AJB10.1843

Solaiman, A. H. M., Nishizawa, T., Roy, T. S., Rahman, M., Chakraborty, R., Choudhury, J., Sarkar, M. D., \& Hasanuzzaman, M. (2015). Yield, dry matter, specific gravity and color of three Bangladeshi local potato cultivars as influenced by stage of maturity. Journal of Plant Sciences, 
10(3),

108-115.

https://doi.org/10.3923/jps.2015.108.

115

Sudarmadji, S. (1984). Prosedur analisa untuk bahan makanan dan pertanian. Edisi Ketiga. Yogyakarta: Liberty.

Sutrisna, N., \& Surdianto, Y. (2014). Kajian formula pupuk NPK pada pertanaman kentang lahan dataran tinggi di Lembang Jawa Barat. Jurnal Hortikultura, 24(2), 124-132. https://doi.org/10.21082/jhort.v24n2. 2014.p124-132

Xing, Y., Niu, X., Wang, N., Jiang, W., Gao, Y., \& Wang, X. (2020). The correlation between soil nutrient and potato quality in loess plateau of China based on PLSR. Sustainability (Switzerland),
12(4),

$1-17$. https://doi.org/10.3390/su12041588

Yuniarti, A., Suriadikusumah, A., \& Gultom, J. U. (2017). Pengaruh pupuk anorganik dan pupuk organik cair terhadap $\mathrm{pH}, \mathrm{N}$-total, C-organik, dan hasil pakcoy pada inceptisols. Prosiding Pertanian Dan Tanaman Herbal Berkelanjutan Di Indonesia, 213-219.

Zhang, W., Liu, X., Wang, Q., Zhang, H., Li, M., Song, B., \& Zhao, Z. (2018). Effects of potassium fertilization on potato starch physicochemical properties. International Journal of Biological Macromolecules, 117, 467-472. https://doi.org/10.1016/j.ijbiomac.201 8.05.131 